\title{
Delimiting Geopolitics: a formal approach to define the geopolitical subject
}

\section{Delimitando a Geopolítica: uma abordagem formal para definir o sujeito geopolítico}

\section{DE LEON PETTA GOMES DA COSTA}

\section{INTRODUCTION}

After several years of neglect, the term "Geopolitics" has been more explored in recent years by academics and the media. This can seem, in general, as a good development, as it relates public opinion to foreign policy and internal territorial management. However, in few instances has the term Geopolitics really been related to the concept and has basic geopolitical study been proper used and applied. Furthermore, the discussion is sometimes not even related to geography by itself, but the term is rather misused in discussions that only focus on international security, nationalism or even international relations without a geographical or spatial approach.

Besides its definitions being extensively explained and explored (sometimes even more) in the last century by old theorists like Friedrich Ratzel, Rudolph Kjellén, Karl Haushofer or Halford John Mackinder and more recently Yves Lacoste or Saul Bernard Cohen, the limits to consider in determining whether a subject, event, analysis, or article is related to Geopolitics still remain poor and vague, creating voids and gaps that can be filled with anything that an author desires to be a geopolitical issue. Like in the past, when Geopolitics was misused and reinterpreted as the German concept of Geopolitik, almost banishing the main term from academics, the same problem has returned through the overuse of the term in banal cases and situations not related to Geopolitics and, even more dramatically, in situations not even related to any idea of geography or spatial conception. In fact, this can trigger dangerous situations that can render

De Leon Petta Gomes da Costa - Doutor em Geografia Humana pela Universidade de São Paulo. 
geopolitics a pseudoscientific field to justify a supposed strategic vision of a malicious author who wants to do something and support it with an eventual geopolitical concern. For this reason, it is important not to create another definition of Geopolitics but rather develop a precise delimitation of its boundaries to determine when such issue, event or article is or is not a geopolitical subject of analysis and, furthermore, when a movement of such a country is related to its geopolitical ambitions.

It is the intention of this research to evaluate different samples in which the term Geopolitics was employed to analyse when the term was or was not correctly applied. Furthermore, by these samples, the subject of Geopolitics can be separated and identified to determine when such a report or study is or is not related to the main term and to suggest a methodological chart to delimit when the term Geopolitics may be properly used.

\section{FROM “BAD SCIENCE”TO IGNORED SCIENCE}

After World War II, several academics related the concept of "Geopolitics" to a militaristic view linked with the German Geopolitik and the concept of the politically and militarily dominated space of Lebensraum (living space). This eventually resulted in a distance between Geopolitical studies and other academic areas, especially Geography, in North America and Europe. In fact, there was not a single book title in English using the term geopolitics between the 1940s and 1977, with the exception of Sen's Basic Principles of Geopolitics and History, published in India in 1975, and there were few such papers in geographical or political journals. During this period, even with some scholars advocating that geopolitics retained a fundamental value and that its neglect could be both politically and intellectually dangerous, some academics remained very critical, arguing that anything of value in geopolitics was contained within political geography and that geopolitics should be abandoned completely as a scientific term, except for historical connotations or in cases where its revival was considered very premature. The contours of some Geopolitical subjects were appropriated by the political science, strategic studies and international relations literature or limited to military academies and staff colleges, with only occasional aspects coming to the surface in publications, but even in these cases, very few contributed new literature or analysis to the public debate. In general, the conclusion must be that geopolitical writing declined in both language and substance (Hepple 1986). It is important to note that the term Geopolitics was academically neglected, but the foreign policy of many governments was still guided by Geopolitical objectives and goals, such as the United States policy of 
containment in the late 1940s and its approach to China in the 1970s, the Cuban situation for the Soviet Union, and even the French and English adventures in the Suez Crisis. However, it is worth of note the fact that this rejection was stronger in Europe than a general feeling in the academics. Especially in United States (as already cited), Brazil or Chile for example, that kept a regular basis of geopolitical writings. In Brazilian and Chilean cases, probably because their military governments during that period. In other countries, in turn, Geopolitics was normally limited to branches of some departments and not open to the general public or academics, like the former Soviet Union and China (where still is a closed subject), due to its sensitive issues.

In 1974, the Swiss P. Guichonnet and C. Raffestin published their work about frontiers, and the French Yves Lacoste (Costa 2008) initiated a quasi-revolution in discussions of political geography, first with the Hérodote Journal and later with the book "La Géographie, ça sert d'Abord à Faire la Guerre", both in 1976. The Hérodote Journal would shake the discussions of strategy and ideology by recognizing the crisis that geography was suffering at that moment because of its excessive pragmatism and depoliticization. Later, an editorial of the founders in 1986 would say that Hérodote (at that moment) was responsible for articulating the Geographical method and Geopolitical analysis. Yves Lacoste stated that Geopolitics was not a monopoly of Ratzel (Ratzel 1983 apud Costa 2008) and his Nazi followers or a Hitlerist concept by arguing that Geopolitics was a concern even for Élisee Reclus (Maspero 1983 apud Costa 2008), a geographer and anarchist and clarifying that it was not a change in his orientation but rather an explanation of characteristics. In fact, Lacoste considered the use of the term Geopolitics by scholars (and the geographers who were the most capable of this) something natural, as they should be explicitly dedicated to this subject. Furthermore, he proposed a critical Geopolitics more related to peace, social justice and democracy (Costa 2008). The matter around the concept was even more sensitive to some countries like Brazil and Chile, where some scholars linked the Geopolitical writing and national security of Brazil and Chile with the geopolitics of fascist Germany, arguing that the historical context and connection reflect its logic and structural connections (Cavalla and Chateaux 1977). Furthermore, the troubled figures of these countries were directly involved in Geopolitical studies, like the former dictator president of Chile, General Augusto Pinochet Ugarte, and General Golbery do Couto e Silva in Brazil, chief of the SNI (the Brazilian intelligence agency during the military dictatorship) (Chapman 2011). To Peters (1999), the term geopolitics was a substantial element of Western foreign policy during the Cold War against the world under 
influence of its rival, the Soviet Union. As a concept to explains the competition for spheres of influence, driven by the fear in the Western camp of a 'strategic strangulation' by the Soviets.

However, Geopolitics barely had regained its centrality in academic discussions when a new "crisis" arrived to Geography by itself. The 1990 s and the Post-Cold War Era give a boost to liberal idealism, bringing hard statements like the weakening or even the end of the borders, the inevitable spread of democracy and the loss of the importance of the Geography in a globalized world. Francis Fukuyama argued that the triumph of Western liberal democracy and the free market predicated some form of universal state in a new world, where Geography would have less importance, borders would be useless, and national issues would be more homogenous $(+1992)$. In national security matters, even a new generation of threats, like organized crime, terrorism and other non-state agents, would be more important than the older security model based on States as a threat. This "new world" would have deprived the State of its sovereignty with many new globalized threats that do not respect the borders. Furthermore, new technologies would make geography less important than ever. Therefore, the mobility of people and products would drastically increase and lower transaction costs. In fact, geography would be irrelevant in this New Age because irregular (non-state) actors would use the Information Age and cyberspace in a global level of communications, with the resulting absolute loss for the nation-state of the ability to control the mass media and cybernetic space due to widespread access by the population to digital information. In other words, the State would not be able to shape public opinion or control the cyber-criminal enterprises that could hurt its sovereignty (Naim 2006). In this flat world, the concept of space would be useless, like the New York Times columnist Thomas L. Friedman (2007) has stated. In fact, the sentence "because the globalization..." turned into a general motto or excuse to explain almost any situation, some of them not even really new but only interrupted by the Cold War.

This process of globalization, initially developed by National States, acquired its own life, developing to even threaten its creators (the StateNation) by its logic and consequences. The implications of the current form of globalization would establish a new pattern of development that could make it at odds with the notion of the old state system (Backer 2004). In this Post-Cold War New World, Geography would be irrelevant, and the Nation-State would die. A vision much shared by academics in the 1990s was that Geopolitics would be something useless and a Cold War relic of an outdated world that no longer existed. Some of these perspectives of a "global fluidic" world remained even after the terrorist attacks in 
New York and Washington in 2001, based on the excuse that they were only possible because of their peculiar historical and technological moment (Bonanate 2001). Even today, it is not hard to find speeches trying to present the idea of a useless Geography or that Geopolitics lost its meaning in the globalized world. This idea was sometimes connected to the global War on Terror, a supposed new form of war without borders and without a territory.

\section{THE RECOVERY OF GEOPOLITICS AS A VULGAR USAGE}

In the 1990s, some authors noticed the reborn of the term "geopolitics", even among regional groupings, which had abstained from any kind of power aspect in politics, as the European Union for example. As well the problematic precision of what constitutes the Geopolitical Power. With several military, humanitarian and economic crises in the decade of the 2000s, along with the creation of political/economic/military news blocs and several studies and publishes predicting a more complicated world, there was an attempt to take back the idea of Geopolitics, especially because it is a concept that suggests and connotes an idea of a strategic and scientific accurate situation. The Geopolitical perspective attracted greater attention in the academic and popular views. However, this led to a misconception of what Geopolitics really is and when an incident was a geopolitical scenario, confusing it with a regular political or diplomatic event, an economic investment, or a minor international security issue rather than the main concept. In fact, the term Geopolitics became overused, extensively employed in situations just because some map was involved, or even worse, in cases where there was no Geography at all.

It is possible to take as an example some journal articles of Brazilian newspaper columns "trying to analyse" football and the World Cup from a geopolitical perspective. An issue without any Geopolitical context. For example, "World Cup and the Geopolitics" (Copa do Mundo e a Geopolítica), which the author makes a deep economic and political (even sociological) analysis of the World Cup and the participating teams of the tournament, something regarding the nationalism and the feelings involved in the tournament. Or "Geopolitics and Football" (Geopolitica e futebol), an analysis only about the performance of the teams in the World Cup of France (2002). In both cases, there is not a single direct (or even indirect) relation to Geopolitics, and in fact, there is no Geography involved at all. There is some confusion in mixing nationalism, flags, and performance in the games with a Geopolitical situation, in which even a microlevel of Geopolitics is not involved. In "Sexual Salvation: Affirming Women's Sexual 
Rights and Pleasures", there is a chapter devoted to the history and the geopolitics of prostitution, with an extensive use of Geography and geographical explanations of different situations of prostitution and sexual slavery around the world, but there is not even a single bridge to connect the subject to a geopolitical context (Mccormick 1994). In fact, even former Secretary of State Henry Kissinger (partly responsible for the rebirth of the term in the 1970s and 1980s) overused the term. Besides the spatial element that was always present in his speeches, the geographical content was often unclear (Hepple 1986).

Another situation that can be a context of confusion is the Chinese involvement in Africa (Florcruz 2015). The obvious Chinese interest in Africa and its investments in African countries are typically seen as a Geopolitical movement and expansion. However, such a term is not so often used in situations involving European (Doya 2015) countries' investments or those of Japan, even though Japanese investments are three times larger than those of China in African countries (Crowley 2015). Hence, despite Africa being a common interest for every large or relevant country in the world, investment in that region is only perceived as a Geopolitical movement when it is convenient to sketch a more militaristic or "sinister" scenario. Despite the article's claim of a possible military interest in this case, there is no evidence to support it.

Even the employment of military personal does not necessarily indicate the Geopolitical interest or ambition of the countries involved in the situation, especially peacekeeper missions. MINUSTAH, the United Nations peacekeeping mission in Haiti since 2004 (United Nations), for example, comprises military forces from many countries (twenty countries currently). Although it includes countries with an interest in the Caribbean region such as Brazil and USA, it also includes countries for which it would be harder to argue any type of geopolitical interest in the Caribbean region, like Philippines, Jordan and Nepal. The same applies in MINUSCA, the United Nations peacekeeping mission in the Central African Republic (United Nations), which would be difficult to call a geopolitical area of interest to Bhutan, Bolivia or Serbia, despite their participation in the mission. This type of situation represents more a diplomatic goal than a geopolitical one. In fact, even participation in a direct military engagement does not necessarily represent a Geopolitical interest, as seen in the Iraq War in 2003, where the Coalition Forces comprised countries such as Poland, Mongolia and Nicaragua, who had no direct Geopolitical goal in the region.

The same logic can be applied to the "Lobster War", when France and Brazil disputed the rights of lobster fishing in a Brazilian maritime region 
in 1961. Despite the direct economic interest of the France in fishing lobsters, it hardly proves or indicates that Pernambuco in Brazil was inside the French Geopolitical interest. This discussion is important to show that even military conflicts or crises do not necessarily mean that there is a Geopolitical direct interest. In fact, the word "Geopolitics" is largely deployed in cases in which there is no direct involvement with a Geopolitical background, and this overuse is the result of confusion not only by the media but also by academics who mix this concept with generic geographical information without any basic Geopolitical connection, or in more problematic cases, without even the use of Geography or a map, just a political or a social situation. Although the discussions around Geopolitics, leading to its increased attention in recent years, can be viewed as being generally positive, several precautions must be taken to avoid the unnecessary and excessive use of the concept, causing deterioration to the main subject of Geopolitics.

The formal definition of the term is a very old discussion, not only between geographers but also political scientists, with several approaches to this objective. Besides the delimitation of Rudolph Kjellén (Kjellén 1917 apud Cohen 2003), who defined Geopolitics as being "the theory of the state as a Geographical organism or phenomenon in space", that of Edmund Walsh, who stated that it is "a combined study of human geography and applied political science... dating back to Aristotle, Montesquieu and Kant", and that of Saul B. Cohen, who defined it as an interaction between geographical settings and political processes (Cohen 2003), the main problem is not to define what Geopolitics is but rather when a study of a case, subject of analysis or political movement is a Geopolitical matter (Geopolitical Subject). As I already demonstrated, several cases referred to as topics of "Geopolitics" are not even close to geopolitical cases. The frontiers to specifying Geopolitics still remain too far open and vulnerable to be interpreted as any writer wants.

Leslie W. Hepple stated the same problem in 1986:

Geopolitics serves as an umbrella term, encapsulating the interaction of global and regional issues with economic and local structures. But the term geopolitics often appears only in the title, introduction and conclusions, with no linkage to other geopolitical literature, and with the major analysis being conducted using other political and economic intellectual frameworks, usually with little geography and few maps.

In his criticism of the overuse of the term "Geopolitics" in 1986, Hepple points to several studies containing geographical or spatial information 
(some of them with no geography at all) but with lack of geopolitical data or relevance, like Geopolitics of Information (many studies with the same title have been published in the last years and with the same hardly problematic use of the term) and Géopolitiques de l'Apartheid (Geopolitics of Apartheid), which provide an analysis of the territorial and spatial logic, but with no Geopolitical subject or literature involved. The lack of history or critical philosophy may not only "reinvent the wheel" but misrepresent the concept by creating a blank check to consider any subject a strategic issue without providing any discussion of social and political aspects or/ and models, which must be always involved in social constructions such as geopolitics.

According to Hepple (1986):

The more general, popularized use of geopolitics is very vague in approach, far away from any geopolitical or geographical tradition, and whilst the contributions are often original and valuable, they seem to be searching for an appropriate framework under the general heading of "geopolitics".

\section{WHEN IS AN EVENT A GEOPOLITICAL MATTER?}

After exposing the two extremes of the treatment of Geopolitics, from its exclusion from academia to the extensive and unnecessary use of the term, I want to raise a discussion to refocus on the core of geopolitics to define when an event is really a geopolitical matter and subject case of study or analysis. For this reason, I want to introduce some patterns, dimensions and theories to summarize when a subject can be considered a Geopolitical matter.

According to Saul B. Cohen, the structures of Geopolitics are composed of patterns like shape, size and the characteristics of human geography (like demographics), physical geography (like climate and topography), and features around political geographical areas, nodes and borders. These structures are hierarchically arranged in spatial layers or levels: the geostrategic realm, the macrolevel; the geopolitical region, a subdivision comprising the mesolevel; and national states, quasi-states or territorial subdivisions, the microlevel. Cohen also divides the geographical settings into maritime and continental and reunites the Geopolitical features into Historic or Nuclear cores, the areas in which national state originated; Capitals or Political Centres, where the political and symbolic government rules the population of the delimited territory of the State; Ecumenes, the greatest demographic or economic areas; Effective National Territories 
and/or Effective Regional Territories, the moderately pro-state population areas; Empty Areas, essential areas devoid of population; Boundaries, the mark and limit of the national states; and Nonconforming Sectors, areas with separatism sentiment (Cohen 2003).

Meta-Geopolitics, the geopolitics related to the outer space, suggested by Nayef Al-Rodhan, is constructed according to the seven dimensions that countries involved in large space programs possess: Social and health issues; Domestic politics; Economics; Environment; Science and human potential; Military and security issues; and International diplomacy (Al-Rodhan 2012). Five of his dimensions can be directly connected to the Geopolitical context of the national States, like Social (demographics), Domestic politics, Economics, Scientific potential and Military issues. These five characteristics, grouped into a set, can shape not only the internal geopolitical reality of such country but also its foreign policy interests and capacity to protect or extend its sphere of influence. In other words, this model of dimensions proposed by Al-Rodhan can help in part to define and delimit if such a subject of analysis can or cannot be considered a geopolitical issue by comprising these five points from a geographical perspective and also the geopolitical potential of each state (or non-state) actor.

Peters (1999) modified the Lacoste's definition by extending the term territory to include maritime and airspace elements, especially because rivalry between two antagonists, especially national States (but not only), are rarely limited to the territorial sense of on-shore territory. Especially because natural resources are also located in the sea, and the control of maritime zones or airspace are indispensable for sustain such power over a delimited piece of territory. Like Al-Rodhan (2012) would do it later by expanding such projection of spatial power to the outer space in modern space program races. Peters also extend this definition with the inclusion of rivalries between groups of States, for example Western OECD against non-Western states, in general she defines the geopolitics term as an analysis of power between different types authorities for political (ideology) and economic dominance over a delimited territory.

Among State strategists, not only Kissinger but also Brzezinski (1997) extensively used this approach by explaining the geopolitical base was no longer the geographic part of Eurasia as a point of departure for continental domination, but a fundamental that moved from the regional space to a global dimension, while the Eurasian continent would be the central core of a global primacy. In fact, the term of "Geostrategy" for him would be a long-term management of America's Eurasian geopolitical interests. Finally, to Brzezinski the geopolitical approach to the "Eurasian Geostrategy" was a: 
management of geostrategically dynamic states and the careful handling of geopolitically catalytic states, in keeping with the twin interests of America in the short-term preservation of its unique global power and in the long-run transformation of it into increasingly institutionalized global cooperation. To put it in a terminology that hearkens back to the more brutal age of ancient empires, the three grand imperatives of imperial geostrategy are to prevent collusion and maintain security dependence among the vassals, to keep tributaries pliant and protected, and to keep the barbarians from coming together.

Considering the geopolitical literature, I propose a definition to address when a particular subject analysis may or may not be considered a geopolitical subject by the simultaneous convergence of three fundamental aspects (Politics, Economy and Military) inside the specific geospatial sphere of a particular country or political actor (non-state actors may also be interested in geopolitical strategy). The economic aspect must be regarded, for areas that provide a fundamental or vital resource are fundamental to the production of an essential good or are fundamental places on trade routes that provide necessary logistics for these vital resources, so that their loss could or will damage the economic functioning of such a country; in other words, these areas should be controlled directly or indirectly for the State to survive. Although the logistical importance of this aspect is largely based in a Mahanist vision of military naval power and controlled seaborne commerce interdependence (Mahan 1890), it must also be applied to land areas. Those economic considerations are important to separate investments that every state or non-state actor normally pursues from a geographic area of interest that is fundamental to the economic existence of such a political organization.

As previously demonstrated, even the most classical and associated aspect of geopolitics, the military, is not always necessarily guided by geopolitical ambitions, so it is important to delimit when a military involvement is or is not inside of the geographic sphere and when a region is considered a geopolitical area of interest of a country. For this reason, the security aspect can be split in two different segments, the external projection capability, which includes conventional military forces (Army, Navy and Air Force), and the capability to maintain control of the central authority within its own territory, normally executed by public security agencies (police departments, for example), especially in nonconforming sectors. Such military involvement can be considered as geopolitical factor 
if linked to a delimited geographical space that is important to the economic survival of the state (as previously explained) and/or politically important; in the vast majority of cases, the Geopolitical area of interest is around the borders of the national states that ensure the projection of its sphere of political influence. In the case of the internal security agencies, their task is to establish and maintain social and political order in the state's territory, avoiding problems such as separatist organizations, organized crime and/or terrorist groups that can eventually lead to some type of territorial loss of state power.

The third and most subjective aspect is regarded to politics. Again, it is important to split this aspect into two different segments, Demography and Diplomacy, which are the internal management of the population inside the national territory, especially in nonconforming territories, to ensure the presence of the central authorities inside its own borders, and the capacity of the external influence of such country on other countries through diplomatic means, where the ability to maintain control or influence over the political actors (does not need be the government by itself) of a region or a country within its sphere of influence or area of interest is crucial for its strategic interests in that country or region. There are many possible ways that governments can apply this procedure through soft power diplomatic acts, some of them by controversial actions that can involve even bribery.

A Geopolitical subject must involve more than a military operation, financial investment or diplomatic or territorial management; the three aspects must be combined simultaneously and based in a geographical plan to consider such an object of analysis as a Geopolitical issue of study. This delimitation is important to guide and separate the different layers of discussion in areas of the humanities, avoiding confusion with different segments of studies like International Security, Political Science and Economy. Furthermore, it makes it clear that Geopolitics is not the same as nationalism, diplomacy or geography, but it can sometimes be related. Above all, it is not necessarily a concept to justify some type of Imperialism, but a geopolitical strategy can also develop a defensive policy to deal with potential external threats in the military, economic and/or political spheres of a country or countries, leading a group of countries to develop countermeasures and partnerships like trade blocs or military alliances. Additionally, it is important to establish that Geopolitics is not exclusivity for foreign policies or international relations, as normally stated (Devetak et al 2011), but may drive territorial management in their homeland policy. I suggest the following schematic that tries to simplify and clarify the main idea: 


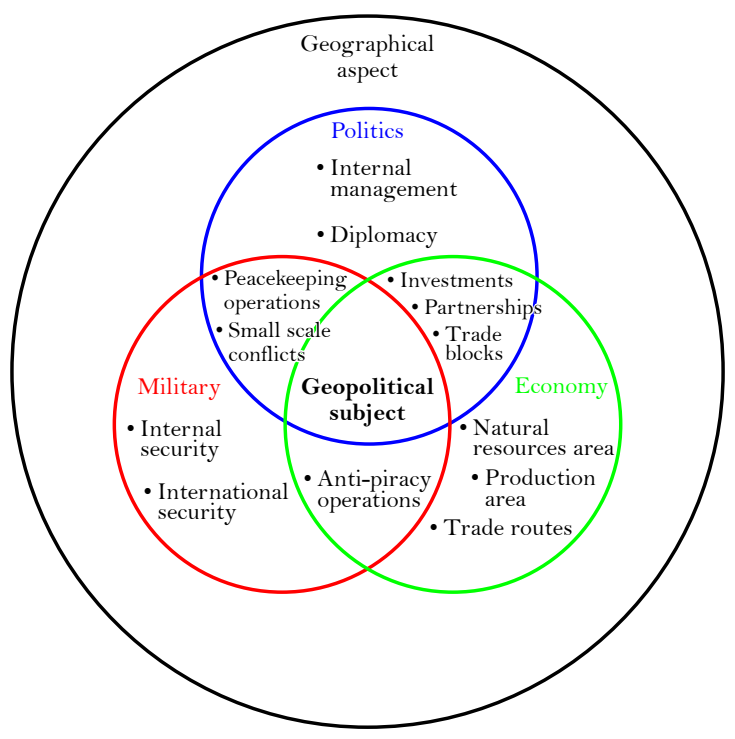

This graphic illustrates when a subject is a Geopolitical matter by the confluence of the three spheres (aspects) inside a larger sphere based on a Geographic/Spatial plan. For example, besides the political and economic aspects of BRICS and several claims about its Geopolitical arrangement (Leahy 2014), there is not only no military ambition in the involved countries, but, more importantly, there is a complete lack of a geographic and spatial relationship between them, configuring it as a political-economic bloc, not even close to a geopolitical ambition. In this way, it is very different from the Shanghai Cooperation Organisation or the North Atlantic Treaty Organization. Meanwhile, even small-scale conflicts, due to their scale, would hardly relate to a geopolitical situation, including the war on drugs or/and war against terrorism. Military engagements against these assets are punctual and do not mobilize all aspects simultaneously, except if this non-state actor eventually evolves to operate in all three aspects in a particular delimited geographic region, such as the Islamic State briefly was able to achieve. ${ }^{1}$

There are some factual situations that can also demonstrate when the term can be properly applied, like in the classical Mahan theory regarding the Canal in the Isthmus of Panama (Mahan 1890), involving the geographical aspects that reduced the distance between the two North American coasts by 8,415 geographical miles (Mills 2010), directly affecting the economic and the military logistical structure of the United States and to guarantee the political interests in the region. The American gov- 
ernment has always held some type of political influence over Panama, even that of the troubled and obscure involvement with General Manuel Noriega and his corrupt government related to drug trafficking (Marcy 2010). In this case, it is very easy to identify a subject of analysis in the Caribbean and Central America as related to Geopolitics due to the confluence of the geographical factor with the three aspects.

This perception is not so far from Brzezinski (1997), in fact it based on. He explored what was called "Geopolitical pivots". States with importance derived from its very sensitive location and from the consequences of its potentially vulnerable condition. Those geopolitical pivots are determined by their geography, in some cases having a special role either in giving access to important areas or in denying access to resources to another significant player (in general he refers to national States). While in other situations, those geopolitical pivots can play a defensive shield for a vital State or a region. Sometimes, according to him, the existence of a geopolitical pivot can have a significant political and/or cultural consequence for neighboring player. Many years later, Brzezinski (2012) would still sustain such methodology and views of what Geopolitics is by presenting Georgia, Taiwan, South Korea, Belarus, Ukraine, Afghanistan, Pakistan, Israel and the Great Middle East as the Geopolitically most endangered States while using the same methods that he defined as "Geopolitical pivots".

It is not ironically neither coincidence the fact that those Geopolitical pivots are regions/countries/areas of friction between bigger State powers. In fact, such geographical places turned in pivot areas because they are inside a bigger structure of geopolitical dispute among regional and/or global powers. To define when such matter is or not a Geopolitical Subject of study (and by consequence related with Geopolitics) the researcher must consider such context of frictional disputes because the subject of study in this theme are normally inside this context.

An example where the term cannot be applied is the Chinese geopolitics in Africa. Despite many media articles arguing about the geopolitical interests of China in the African countries, there is no clear evidence that supports it. As previously stated, the Chinese investments in Africa are not the largest among other non-African countries. Furthermore, at this point, the Chinese government has not deployed any military asset or base in Africa, and even with several reports and media news describing the possibility (Benabdallah 2015), it is hard to sustain such a position. Even the Chinese naval presence against piracy in the Gulf of Aden (BBC 2008) cannot be considered geopolitical, as it seems to be more related to a multinational task force for peacekeeping than a military engagement. Furthermore, besides the financial investments, there are few signals or 
evidence of a Chinese direct influence over the local political elites. In fact, the Chinese geopolitical maritime areas of interest are more related to "vertical" expansion near its coasts, in the South China Sea and East China Sea, than a "horizontal" expansion that could eventually go towards Africa (Kaplan 2010). These examples demonstrate that in several cases, there is double standards in use of the term "geopolitics.

Another common mistake, which unfortunately is growing, is the split between Geo-economics from Geopolitics, like if eventually one could surpass another. For example, Søilen (2010) who stated:

Geoeconomics is gradually replacing the importance of Geopolitics. The transition is marked by the start of the process we call Globalization about two decades old now, but still in its infancy, when government and government institutions discovered that they no longer were self-evident key actors and watchmen of world events. The process is an effect of the end of the Cold War and marks a strategic shift from political ideologies to economic realities.

A statement absurdly wrong because it does not understand the fact that the economy is directly affected by security/military issues, as clearly observed by Mahan more than a century ago, the close relation and interdependence between these two is what defines the modern strategy and economic stability in the world. Especially in the Chinese situation regarding the China's Maritime Silk Road Initiative, considering the obvious fact that connectivity and infrastructure projects are integral element of global political and economic power. The China's Maritime Silk Road Initiative (MSRI) and the Silk Road Economic Belt (SREB), also known as "Belt and Road" or "One Belt, One Road" (OBOR) initiative, are contemporary connectivity geopolitical projects due to the financial and geographic scale of these projects. Through several economic actions is possible to see its security background context. For example, the objective to promote the development of western Chinese provinces such as Gansu, Guangxi, Ningxia, Shanxi, Yunnan and Xinjiang. To produce a favorable regional/domestic security environment in China's western areas decreasing challenges of religious extremism, separatism and terrorism. Moreover, reducing the Chinese dependence on sea-based energy transportation routes, especially the Strait of Malacca (Blanchard and Flint 2017). In other words, it is not possible to Geoeconomics replace the importance of Geopolitics, because it is already inside a bigger Geopolitical realm.

It is also important to establish objectives and projection limitations that define if a subject is a geopolitical matter according to the potential of the state actor (or non-state actor) involved, which means that if 
new elements appear, it may change such projections and objectives, in the manner that the Canal of Panama changed the United States' destiny, as predicted by Mahan, by expanding its interests and projection, or like the political transition of the Soviet Union to Russia, decreasing its projection and geopolitical interests. Furthermore, based on these three aspects, if we take the five main dimensions of Al-Rodhan as a sample of the projection capacity, the United States would be the only country with a global geopolitical interest and projection, at least at this point, with all other countries being more or less limited to specific areas around its own borders. In addition to not expanding their geopolitical projection by the five-dimensional limitations, some of their foreign policy interests are also more restricted, like those of China, Russia and India. ${ }^{2}$ However, other cases, like England and France, despite aspiring for greater projection, still suffer from serious limitations. This could lead to a reflection that the maintenance of the United States' geopolitical objectives would necessarily sooner or later crush other states' geopolitical spheres.

These crushes could be represented by the shatterbelt regions, which are strategically oriented regions that are disputed by the competition of Great Powers in geostrategic realms and compression zones, while fragmented areas subject to the completion of neighbouring countries but not Great Powers could be identified as geographical spaces where the geopolitical interests and objectives of different countries overlap and collide with each other. Following the graphic presented before, if fewer than all three aspects collide in this particular place, some sort of competition will start (or in some cases, a deal may be drafted that can turn it into a cooperation or partnership due to its small scale) but would not trigger a geopolitical crisis. In this case, the three aspects should be involved, disrupting a more severe and dramatic situation. As stated by Saul B. Cohen, a good example of a shatterbelt is the Middle East, due to its fragmentation reinforced by a dozen regional states as well the influences and actions of major powers. However, not all areas in turmoil are shatterbelts. For example, the Caribbean did not become a shatterbelt because of the communist Cuba or Nicaraguan uprising in the region, because the United States' sphere of influence was never seriously contested. Similarly, the conflicts in South Asia did not evolve to a shatterbelt because India's sphere of influence in the region is not threatened by the United States or China (Cohen 2003). This could change, though, if the Chinese government eventually makes a major movement in the Strait of Malacca, triggering a regional dispute (Kaplan 2010). Those cases are good to validate the theory represented in the previous chart, on how the terminology of Geopolitics would fill in these scenarios and how the term must be employed only in the case of the 
political, economic and military aspects being involved at the same time inside a spatial sphere.

This elasticity must be also considered as a fundamental characteristic of the Geopolitical Subject. Because the needs and capacity of national States, as well any other political group, will eventually change in time. Boundaries are socio-spatial limits of difference and will define the territorial extent in its legal fact or legitimacy. While at the same time, spatial inscriptions are not static. The hierarchy of territories based on political boundaries are frequently in question, because it involves negotiations for cooperation and competition between interests and identities (Novak 2011). A good example of change of those geopolitical shapes may be found in the European Union expansion and its evolutional integration, a transnational organization not structured on fixed spatial model but based on heterogeneity of dynamics. Although new countries can go in or older members can out, according to its internal and external political context. Also, we must not fall in mistakes by considering that every Security aspect is also a geopolitical subject, because while in several issues both aspects may eventually cross paths, this is not a mandatory factor but just very likely.

\section{CONCLUSIONS}

As demonstrated, several uses of the word Geopolitics are hardly connected to the concept itself. It is not surprising, as geopolitical study suffered significant damage in the last half century, coming from the association with the German Geopolitik for at least three decades to a brief recovery in the 1980s, just to suffer another hit with the overuse of the Globalization concept, sometimes more ideologically guided than scientifically. This crisis in Geopolitics is also because Political Geography, throughout the twentieth century, among the other sub-disciplines of geography, had great difficulty with an autonomous academic reflection not related to the immediate demands of national states, such as those by authors in the United States like Spykman and Mahan, Mackinder in England or Haushofer and Ratzel in Germany. Most of the theoretical constructions of classic geopolitical thinking still remain much more determined by the demands of the States than by proper intellectual needs, characteristics of a more academic "pure" reflection. In some Latin countries, geopolitical thought was produced by intellectuals related to the Military, directly linked to the military dictatorships in that time, as in the case of General Golbery in Brazil and General Pinochet in Chile. After the democratization of such countries, the collapse of the Soviet Bloc, 
the "End of History" and the "End of Borders" speeches, Geopolitics and Geography lost much space in the Academy. The design of an academic geopolitical thinking produced by civilians or unrelated to national State demands is still in its infancy in several countries.

Although the main "Geopolitical Subject" is the national State (at least in most cases), its analysis does not need to always be determined by National interests, but several forms of analysis and knowledge can be offered that may help analysts and researches understand the "bubbles of power" (political groups oriented in such spatial dimensions by one or more of the three aspects previously presented) that comprise the national and international scenarios of analysis. In fact, when such an issue is determined to be a Geopolitical subject, it will demonstrate how deep such a situation is and how much problematic it could become, due to the involvement of the Political, Economic and Military aspects at the same time. A popularization of the term relating the Geopolitics concept to non-sense matters such as football and prostitution, among others, is bad for the concept and bad for the readers who may not be able to understand the complexity and importance surrounding the geopolitical interests.

The importance of delimiting a methodology for Geopolitics and the Geopolitical Subject beyond the basic literature of Mahan, Ratzel and Mackinder is because geopolitics presents an important key that drives and guide foreign policies and even national policies. Therefore, its popularization and use without the geopolitical literature or spatial or geographical elements is dangerous, not only for the term itself and the geopoliticians who spend much time studying, writing and analysing the area but also for State and non-state actors that require a geostrategic orientation. As a blank check, the concept can mislead and open doors to any type of political action like the Lebensraum concept in the name of national security or a strategic issue, causing severe damage not only to the science of geopolitics but also to the public who can be misguided. Hence, the Geopolitical Subject must be delimited by the Geographical aspect and composed of political, economic and military aspects, simultaneously, to determine when Geopolitics matters.

This exact methodological delimitation, is far more important than only avoiding misinterpretations, it can also help to prevent another assault against Geopolitics and Political Geography, making it difficult to relate them to the Nazi concept of Geopolitik by avoiding an imminent connection with imperialistic acts (because it can be used to develop a defensive geostrategy) and by stating its permanent and strategic importance in the world, even on such a globalized planet. Because Geopolitics is a four-dimensional field of study (not only related to the spatial dimensions but 
also the temporal), the proposed chart can also provide a guided orientation more accurate for studies, diplomatic actions and the public. Many political, economic or military reasons in time will change the shape the projection and gravity of the Nation-States. Something recently observed in the dissolution of Soviet Union (a retraction form) which lost its influence and capability over some territories, or in China rising (an expansion form) which is gradually absorbing more abroad areas as a form to sustain its "geopolitical energy". To conclude, a one- or two-aspect conflict or crisis (Political, Economic and/or Military) is far easier to peacefully resolve than a Geopolitical crisis, due to the combination of the three aspects at the same time inside a geographical sphere that is normally fundamentally important for the states (or non-state actor) involved to survive. In other words, Geopolitics is also important as a delimited term, to show how deep such a situation could be.

\section{ACKNOWLEDGEMENTS}

I am grateful for financial support provided by the FAPESP (São Paulo Research Foundation-Process: 2014/25291-0). I also would like to thank the University of Hong Kong and Prof. Dr. Karen J. Laidler for hosting me while I pursued this research.

\section{REFERENCES}

Al-Rodhan, Nayef R. F. 2012. Meta-Geopolitics of Outer-Space. An Analysis of Space Power, Security and Governance. Palgrave Macmillan. pp. 25.

Backer, Larry Catá. 2004. Cuban Corporate Governance at the Crossroads: finessing the tensions between Cuban Marxism and Free Market Globalism. Journal of Transnational Law \& Contemporary Problems. v. 14, n. 2, p. p.ini. - p. fin.

BBC. Chinese ships will fight pirates. BBC News. (18 December, 2008). Available at: http://news.bbc.co.uk/2/hi/africa/7789303.stm Accessed at: 2016, 4 March.

Benabdallah, Lina. What's the deal with China's new military base in Djibouti? Africa is a Country. (May 18, 2015). Available at: http://africasacountry. com/2015/05/what-does-it-mean-that-china-has-a-military-base-in-djibouti/ Accessed at: 2016, 4 March.

Blanchard, Jean-Marc F; Flint, Colin. 2017. The Geopolitics of China's Maritime Silk Road Initiative. Geopolitics, 22:2. pp. 223-245

Bonanate, Luigi. 2001. La Guerra. São Paulo. Estação Liberdade. pp. 1-20 
Brzezinski, Zbigniew. 1997. The Grand Chessboard, American Primacy and its Geostrategic Imperatives. Basic Books. pp. 21

Brzezinski, Zbigniew. 2012. Strategic Vision: America and the Crisis of Global Power. Basic Books.

Cavalla, A. Chateaux, J. 1977. La Geopolitics y el Fascismo Dependiente. Revista "PRINCIPIOS”. Mexico City: Casa de Chile. Available at: http://www.blest.eu/ biblio/cavalla/index.html Accessed at: 2016, 4 March.

Chapman, Bert. 2011. Geopolitics, A Guide to the Issues. Praeger. pp.13-20.

Cohen, Saul Bernard. 2003. Geopolitics of the World System. Rowman \& Littlefield Publishers. pp. 11, 33-43

Costa, Wanderley Messias da. (2008). Geografia Política e Geopolítica. Edusp. pp: 243 .

Crowley, Kevin. Japan Has Invested More Africa Project Financing Than China. Bloomberg. (2015, 24 March). Available at: http://www.bloomberg.com/news/ articles/2015-03-24/japan-has-invested-more-africa-project-financing-than-china Accessed at: 2016, 4 March.

Devetak, Richard; Burke, Anthony; George, Jim. (2011). An Introduction to International Relations. Cambridge University Press; 2 Edition. pp. 492

Doya, David Malingha. European Investment Bank Plans Africa Expansion Amid Growth. Bloomberg. (2015, July 16). Available at: http://www.bloomberg.com/ news/articles/2015-07-15/european-investment-bank-plans-africa-expansionas-economy-grows Accessed at: 2016, 4 March.

Florcruz, Michelle. China's Geopolitical Ambitions Expand To Namibia's South Atlantic Sea Walvis Bay Port. International Business Times. (2015, March 30). Available at: http://www.ibtimes.com/chinas-geopolitical-ambitions-expand-namibias-south-atlantic-sea-walvis-bay-port-1864132 Accessed at: 2016, 4 March.

Friedman, Thomas L. The World Is Flat: A Brief History of the Twenty-first Century. Ed. Picador. 2007.

Fukuyama, Francis. 1992. The End of The History and The Last Man? Free Press. pp. 199.

Hepple, Leslie W. 1986. The Revival of Geopolitics. Political Geography Quarterly, Supplement to Vol. 5, No. 4, S21-S36.

Kaplan, Robert D. 2010. Monsoon: The Indian Ocean and the Future of American Power. Random House Trade Paperbacks. Ebook version. pp. 404-469 
Leahy, Joe. Opinion: the Brics bank is more about geopolitics than investment. (Jul 16 2014). Financial Times Blog. Available at: http://blogs.ft.com/beyondbrics/2014/07/16/opinion-the-brics-bank-is-more-about-geopolitics-than-investment/ Accessed at: 2018, 4 March.

Mackinder, Halford J., “The Geographical Pivot of History”, in The Geographical Journal, na 4, Vol. XXIII, April, 1904

Mahan, Alfred T. 1890. The Influence of Sea Power Upon History. Little, Brown and Company. Available at: http://www.gutenberg.org/ebooks/13529 Accessed at: 2018, 4 March. pp. 25-34

Marcy, William L. 2010. The Politics of Cocaine: How U. S. Foreign Policy Has Created a Thriving Drug Industry in Central and South America. Lawrence Hill Books. pp. 111.

McCormick, Naomi B. 1994. Sexual Salvation: Affirming Women's Sexual Rights and Pleasures. Praeger; 1st Ed. edition. pp. 85.

Mills, J. Saxon. 2010. The Panama Canal. A history and description of the enterprise. The Project Gutenberg Free Ebook. pp. 244

Naim, Moisés. 2006. Illicit: How Smugglers, Traffickers, and Copycats are Hijacking the Global Economy. Rio de Janeiro. Ed. Zahar. pp. 12,135

Novak, Paolo. 2011. The Flexible Territoriality of Borders, Geopolitics, 16:4. pp. 741-767

Peters, Susanne. 1999. The 'West' against the 'Rest': Geopolitics after the end of the cold war. Geopolitics. pp. 29.

Raffestin, Claude, Pour une géographie du pouvoir, Paris, Li br. Techniques, 1980.

Søilen, Klaus Solberg. 2010. The Shift from Geopolitics to Geoeconomics and the Failure of our Modern Social Sciences. TELOS Conference - From Lifeworld to Biopolitics: Empire in the Age of Obama.

United Nations. MINUSCA, United Nations Multidimensional Integrated Stabilization Mission in the Central African Republic. Available at: http://www. un.org/en/peacekeeping/missions/minusca/facts.shtml Accessed at: 2016, 19 July.

United Nations. MINUSTAH, United Nations Stabilization Mission in Haiti. Available at: http://www.un.org/en/peacekeeping/missions/minustah/facts. shtml Accessed at: 2018, 4 March.

Walsh, Edmund. 1944. Geopolitics and International Morals in Compass of the World, ed. H. W. Weigert and V. Stefansson, 12-39. New York: Macmillan. 


\section{NOTAS}

1. The Islamic State failed in achieve international legitimacy, support and political recognition. Otherwise, it would be able to turn itself in a National or governmental player.

2. With an eventual change in its capacities, its interests may change. 


\section{ABSTRACT}

Today the term "Geopolitics" is very used but only in few situations is correctly employed. Normally its mentions are without any geopolitical literature or even geographic/spatial information. For this reason, this research will explore the precision of the Geopolitical Subject.

Keywords: Geopolitics; Political Geography; Geo-economics; Methodology.

\section{RESUMO}

Atualmente o termo "geopolítica" é muito usado mas apenas em algumas situações é corretamente empregado. Normalmente sua menção não possui qualquer literatura geopolítica e nem mesmo informação geográfica/ espacial. Por esta razão, esta pesquisa irá explorar a precisão do Sujeito Geopolítico.

Palavras-Chave: Geopolítica; Geografia Política; Geoeconomia; Metodologia. 